\begin{tabular}{l}
\multicolumn{1}{c}{ AUSTRALIAN JOURNAL OF BASIC AND } \\
APPLIED SCIENCES
\end{tabular}

\title{
Coastal Ecosystems Capacity as a Study Material in Biology Learning in the Coastal Areas
}

\author{
${ }^{1,2}$ Ramli Utina, ${ }^{1,3}$ Abubakar Sidik Katili, ${ }^{1}$ Elya Nusantari, ${ }^{4}$ Yowan Tamu \\ ${ }^{I}$ Department of Biology, Universitas Negeri Gorontalo, Kota Gorontalo, Gorontalo, Indonesia. \\ ${ }^{2}$ Head of Coastal Ecology Based Local Wisdom Research Center,Department of Biology, Universitas Negeri Gorontalo, Kota Gorontalo, \\ Gorontalo, Indonesia. \\ ${ }^{3}$ Secretary of Coastal Ecology Based Local Wisdom Research Center, Department of Biology, Universitas Negeri Gorontalo, Kota \\ Gorontalo, Gorontalo, Indonesia. \\ ${ }^{4}$ Department of Sociology, Universitas Negeri Gorontalo, Kota Gorontalo, Gorontalo, Indonesia.
}

\section{Address For Correspondence:}

Ramli Utina, Universitas Negeri Gorontalo,Department of Biology, Faculty of Mathematics and Natural Sciences, Kota Gorontalo- 96128, Indonesia.

E-mail: ramli.utina@ung.ac.id

\section{ART ICLE INFO}

\section{Article history:}

Received 19 August 2017

Accepted 1 November 2017

Available online 11 November 2017

Keywords:

Ecosystem, Coastal area, Learning, $L K P D$

\begin{abstract}
A B S T RA C T
Background: Coastal ecosystems are a part of earth's landscape and provide considerable benefits in many aspects, including education. Natural science learning, particularly biology learning at schools, in the perspective of ecosystem competence and environment suggests that the learners understand the concept of ecosystem, environment and aware of the environment. Students who learn in schools at the coastal area can learn the ecological system, such as mangrove ecosystem, coral reef and seagrass bed ecosystem directly too. Learners can identify direct objects in their school environment. The development of learners' attitude is closely related to the environment where they live. Objective: To examine the capacity of coastal ecosystems, and to develop it into teaching media for biology classes at schools in the coastal areas.The media was called Lembar Kerja Peserta Didik (LKPD) or students' work sheet. Results: The findings revealed that the learners' understanding of biology, particularly the capacity of coastal ecosystems got increased. It was also found that the study generated the knowledge and scientific comprehension of the capacity of coastal ecosystems, its management and uses in educational principles. In addition, the findings showed that there was an improvement in the quality of LKPD which reflects a scientific approach. Conclusion: The study wassuccessfully conducted and addressed the research questions. Coastal ecosystems can be used to strenthen the scientific process in learning biology. LKPD is one of the learning media. It is expected that the findings can be utilised as one of the learning media that teachers and learners can use during biology classes. Coastal ecosystems, as learning resources in biology classes, can be a strategy for maintaining the sustainability of the existing coastal ecosystem capacity.
\end{abstract}

\section{INTRODUCTION}

The coastal and marine ecosystems in Indonesia are facing threats due to various pressures of humans' interests. The major threat is the conversion of mangrove forest areas into ponds, and the coastal reclamation for the benefit of local settlement infrastructures which damages the ecosystem of seagrass and mangroveforest (Utina, 2017). Coral reefs were damagedwhen fish and cyanide bombs were used for catching reef fish. Such damage has further destructed the ecological function of coastal areas that support the life of the locals. Deforestation has always been associated to poverty especially with the villages located around the forest (Golar et al., 2017). In other words, the damage caused to environment threatens the capacity of human environment supports. These ecosystem and coastal environment damagesshowournegligence towards the ecological system.

Open Access Journal

Published BY AENSI Publication

(C) 2017 AENSI Publisher All rights reserved

This work is licensed under the Creative Commons Attribution International License (CC BY).

http://creativecommons.org/licenses/by/4.0/

\section{() 0 0pen Access}

To Cite This Article: Ramli Utina, Abubakar Sidik Katili, Elya Nusantari, Yowan Tamu., Coastal Ecosystems Capacity as aStudy Materialin Biology Learning in the Coastal Areas. Aust. J. Basic \& Appl. Sci., 11(13): 122-127, 2017 
Human beingsobservethe order of life and nature as a third person but not as a part of the ecosystem and environment itself. This is the reason behind their actions to satisfy theirlife needs without acknowledging the influence of theirattitude andbehaviour towards other living components and natural processes in the environment. In brief, the establishment of human attitude and behaviouris closely related to the awareness of environmental sustainability.

Learning our ecosystem in natural science at school levelplays a major role in the development of learners' attitudes and behaviourin responding to theecosystem and its environment, as well as their understanding of the ecosystemas a concept itself. Ecosystems are the order of living things with nonliving elements in a system that is ecologically influential. Learners can learn this ecological systemby identifying direct objects in their school environment.This learning process is expected to imposea good understanding about the concept of environment,and to reinforce the learners' responsibility upon theenvironment (Utina, 2016). Piaget suggests that the cognitive development level of elementary school students is still at the concrete level of operations and their logic process depends on what they see and experience (Suparno, 2011).

Schools in coastal areas can utilise coastal ecological systems as 'learning objects'. Mangrove, seagrass and coral reef ecosystems are the media and study resources for learning coastal ecosystems. The composition of ecosystem and environmental processes along the coast can be observed and understood by learners as a part of themselves, and theircloseness to the biophysical components of the coastal environment. The closeness of human life to their surroundings establishes social, cultural, aesthetic and religious values, transformed into the wisdom and behaviour of the coastal communities who are mindful of their environment (Nusantari et al., 2017).

In coastal ecosystem learning, the basis for character building and caring behaviour towards the coastal environment is the understanding of the ecosystem component composition. In addition, it is necessary to consider learning contexts by linking the learning materials of the coastal ecosystem with the surrounding coastal conditions (Zeidler et al., 2005; Nuangchalerm, 2010), including the social, cultural and aesthetic values of the community, which refer to local wisdom (Subiantoro, 2011; Utina, 2012). Media and learning resources are also formulated in the context of surrounding ecosystem (Utina et al., 2014).

The purpose of the study is to examine the potential forms of coastal ecosystems and to develop itas teaching resources for biology subjects in schools located in the coastal areas. Through this learning,learners may have a solid understanding of the concept of an ecosystem and be mindful of their coastal environment. The significance of this study is that it helps in the development of learners' attitude and behaviour, particularly in utilising coastal natural resources for mutual prosperity and anticipating potential damages on the ecosystem and coastal environment.

\section{MATERIALS AND METHOD}

This study is a development-based study informed by a Four-D (4-D) development model by Thiagarajan (Mulyatiningsih, 2013). The model consists of four stages, namely; definition, design, development, and dissemination. The study, conducted at schools located in the north and south coast of Gorontalo, focused only on the development stage.

\section{Research Procedures:}

The Four-D development model and entailed a number of research procedures, namely: (a) The definition stage, which includes the analysis of core competence and basic competence in the curriculum, learners, materials and tasks, as well as the specification of learning objectives. The analysis of core competence and basic competence was done by examining the syllabus and determining the competence in which the LKPD was developed. The learners' analysis was done to investigate whether or not learners' characteristics and situation correspond to the LKPD. The material analysis aimed at examining the scope of the material of the LKPD, whereas the task analysis intended to identifying the kinds of tasks given by teachers and informed by the LKPD. The specific learning objective limits researchers in developing LKPD so that the LKPD may not deviate from the learning objectives stipulated in the curriculum. (b) The design stage, which entails designing prototype worksheet for learners. The content of the material and the questions presented are closely related to the coastal ecosystems located in the research sites. At this stage, the LKPD development should correspond to the good LKPD components, reflecting a scientific approach. (c) The development stage, which involves a validation by an expert validator, LKPD eligibility assessment by subject teachers, and small group tests. The validation by expert material validator and education expert validator. Further procedures contained a practice test of Biology teachers in order to see the feasibility of LKPD. The small group test for learners was done to see learners' responses on the modified LKPD. This group test was designed to cater to 10 students (Mulyatiningsih, 2013). 


\section{Data Analysis:}

Data were collected by using validation sheets, which were used to collect assessments from validating experts and Biology teachers. The data were analysed using a descriptive qualitative analysis approach. Data on the quality of LKPD were analysed by revising the assessment results of validating experts, teachers and learners from qualitative to quantitative forms with the following conditions:

$\begin{array}{ll}\text { SK (Very Poor) } & =1 \\ \text { K (Poor) } & =2 \\ \text { C (Fair) } & =3 \\ \text { B (Good) } & =4 \\ \text { SB (Very Good) } & =5 \text { (Suratsih, 2010) }\end{array}$

The following formula describes the calculation of mean scores of each aspect.

$$
\begin{aligned}
& X=\frac{\sum x}{n} \\
& \text { Notes: } \\
& \mathrm{X} \quad=\text { Mean scores } \\
& \sum \mathrm{x}=\text { Total scores } \\
& \mathrm{n} \quad=\text { Number of reviewers }
\end{aligned}
$$

(Source: Suratsih, 2010)

Changing the mean scores of each quality aspect into qualitative values, which is subjected to the assessment criteria. The following table presents the scoring (Suratsih, 2010).

Table 1: The criteria for ideal assessment category on each aspect

\begin{tabular}{l|l|l}
\hline No. & Range of Scores (i) & Category \\
\hline 1 & $\mathrm{X}>\mathrm{Mi}+1,5 \mathrm{SBi}$ & Very Good \\
\hline 2 & $\mathrm{Mi}+0,5 \mathrm{SBi}<\mathrm{X} \leq \mathrm{Mi}+1,5 \mathrm{SBi}$ & Good \\
\hline 3 & $\mathrm{Mi}-0,5 \mathrm{SBi}<\mathrm{X} \leq \mathrm{Mi}+0,5 \mathrm{SBi}$ & Fair \\
\hline 4 & $\mathrm{Mi}-1,5 \mathrm{SBi}<\mathrm{X} \leq \mathrm{Mi}-0,5 \mathrm{SBi}$ & Poor \\
\hline 5 & $\mathrm{X} \leq \mathrm{Mi}-1,5 \mathrm{SBi}$ & Very Poor \\
\hline
\end{tabular}

Source: Suratsih (2010)

Notes:

$\mathrm{Mi}=$ Mean Ideal $:(1 / 2)$ (highest ideal score+ lowest ideal score)

SBi = Ideal Standard Deviation : (1/3) (1/2) (highest ideal score- lowest ideal score)

highest ideal score $=$ numbers of criterion $\mathrm{x}$ highest score

lowest ideal score $=$ numbers of criterion $\mathrm{x}$ lowest score

The following formula is used to calculate the LKPD ideal percentage.

IdealPercentage $(P)=\frac{\text { MeanScore }}{\text { HighestScore }} \times 100 \%$

The following table shows how to calculate the ideal percentage.

Table 2: Percentage scale for assessing the ideal quality of products

\begin{tabular}{l|l|l}
\hline No. & Interval & Criteria \\
\hline 1 & $81 \%-100 \%$ & Very Good \\
\hline 2 & $61 \%-80 \%$ & Good \\
\hline 3 & $41 \%-60 \%$ & Fair \\
\hline 4 & $21 \%-40 \%$ & Poor \\
\hline 5 & $0 \%-20 \%$ & Very Poor \\
\hline
\end{tabular}

Source: Aldila, 2013

\section{Results:}

The results showed that the existing coastal areas in Gorontalo possess a quite high capacity of biological resources that are part of the coastal ecosystem. Such capacity refers to the community of mangrove, sea grass and coral reefs, the main components of the coastal ecosystems. The coastal area in Gorontalo has the sociocultural capacity of ecological intelligence of the community. A strong relationship exists between biological resources capacity with the ecological intelligence of coastal communities. This fact is found in Bajo society in Torosiaje village in the Province of Gorontalo. In the neighbourhood of Bajo, mangrove resources and ecosystems, seagrass and coral reefs are well preserved and maintained. However such condition is not though happening in other coastal communities (Utina, R., 2012). The Bajo community who inhabits the coastal area of Torosiaje village has an emotional proximity and thought to their natural resources, which demonstrates real 
attitudes and behaviour by considering the ecological capacity. This community has local wisdom being reflected in a number of existing traditions, rules or restrictions that they pass on, maintain and obey from generation to generation. The potential of coastal ecosystems and ecological intelligence can be used in biology learning resources in schools located in coastal areas (Utina, R., 2017).

The interview results revealed that the capacity of coastal ecosystems had not been thoroughly utilised in learning activities of schools. The interviews conducted with biology teachers inferred that there is no potential utilization of coastal ecosystems for learning resources. In addition, LKPD, used in the learning activities, is still general and has not included local capacity, especially the coastal ecosystems for learning resources. On the basis of these facts and informed by the capacity of coastal ecosystems, the LKPD was developed, reflecting a scientific approach.

The results of validity test for examining the LKPD feasibility by material expert validators revealed that the LKPD development result draft was Very Good with X value in X score range> 28,05. The calculation of the percentage of ideal LKPD, according to the material expert validators, was in the range of $81 \%-100 \%$, which indicated that the level of ideal LKPD was Very Good. In addition to the validity test by the material expert validator, the LKPD was also validated by an expert education validator. The LKPD assessment results from the education expert validator showed that LKPD, according to the education expert validators, was categorised as Very Good with $X$ value in the range of score $X>31,95$. The calculation of the percentage of ideal LKPD demonstrated that the results obtained from the total percentage of LKPD, according to the expert education validator, was in the range of $81 \%-100 \%$, which indicated that the level of ideal LKPD was Very Good. The evaluation phase of LKPD feasibility by biology teachers revealed that the result of score calculation for LKPD is feasible i.e., $X$ value was in the range of score $X>64,05$, which indicated that the LKPD quality was Very Good. The overall percentage of LKPD, according to the biology teachers' assessment, was in the range of $81 \%-100 \%$, indicating that the ideal level of LKPD was included in the category of Very Good.

The small group test results showed that the score for LKPD quality was within the range of X>40,05, which indicated that the quality of LKPD, on the basis of learners' responses, was Very Good. The overall percentage for LKPD, based on the learners' responses, was in the range of $81 \%-100 \%$, which indicated that the ideal level of LKPD was Very Good.

\section{Discussion:}

The stages in LKPD development which utilize the capacity of the coastal ecosystem for the study materials help in addressing research questions framed for the study. Thisshows that the coastal ecosystems have enormous benefits, such as being a source of livelihood for coastal communities, a balancing tool for the ecological system in coastal areas as well as can contribute for education too. The development of LKPD in biology learning that utilises the capacity of the coastal ecosystem has also become as one of the alternative strategies in preserving the coastal ecosystem. This suggests that the learners who use the LKPD maybe sensible to any changes in the coastal areas. In the future, these learners may be able to maintain and preserve the coastal ecosystem.

The importance of awareness and knowledge among the coastal communities about the capacity of coastal ecosystems suggests that the educational aspect strategy is expected to change the way how locals' think and get awareness. Education, formally and informally, should preach the values of the four pillars namely; learn to know, learn to do, learn to understand oneself (self-identity), and learn to live together and respect each other on the basis of equality and tolerance in society. The existence of the capacity utilisation of coastal ecosystem as learning resources for biology classes, in this case for the development of LKPD, is an effort to develop learners' motivation to preserve natural resources and to assist them in learning ethical values of human relationships with nature. Character education can be realised in the form of responding to theenvironment and preserving natural resources.

Natural learning resources, such as coastal ecosystems, can be an option in supporting the biology learning process because it provides learners with opportunities for direct learning outside classroom contexts. In addition, the direct interaction with learning objects allows learners to recognise, find out, analyse, prove and make conclusions about learning objects. This may help them apply scientific principles in their learning, i.e., they not only make opinions without supporting facts but are also encouraged to seek answers for a particular problem or phenomenon that they observe. This is called 'scientific approach activity'.

Scientific approach-based learning is a learning process designed to help learners actively construct concepts, laws or principles through certain scientific stages of an existing phenomenon or event. Scientific approach is one of the learning strategies which is expected to increase the competence of learners and forms the main foundation in the development of the year 2013 curriculum (Riyono, 2013). The regulation of the Ministry of Education and Culture No. 65 year 2013 on the standards of the primary and secondary education processes stipulates that the learning process is informed by scientific approach principles. The efforts of applying scientific approach in the learning process forms the characteristics and strengths of the year 2013 curriculum. 
In learning, learners should not only use books as learning resources, but they can also explore their environment. They can utilise coastal ecosystems as learning resources. Observation and discovery using their own knowledge through what they observe in the coastal ecosystem occurs in this approach in addition to gaining direct learning experience. Direct learning process produces knowledge and skills otherwise called as instructional effect (Rachmawati and Daryanto, 2015). Biology is one branch of science that studies the living things. Biology learning is not only done by reading and memorising things, or a form of communication and knowledge transfer from teachers to learners. The learning should be able to create a direct interaction between learners and learning objects which they learn, such as coastal ecosystems.

\section{Conclusion:}

Development of learning media in the form of LKPD which utilises coastal ecosystems as the study materials shows an increase in learners' understanding of Biology learning about coastal ecosystems. LKPD, as a learning media that is informed by coastal ecosystems, can help teachers and learners in Biology learning. In addition, this study produces LKPD qualities that are within a very good score range reflecting a scientific approach. Utilisation of coastal ecosystems capacity as learning resources in Biology classes can be useful in maintaining the sustainability of the existing coastal ecosystems capacity. This study,can be usefull in the development of learners' attitude and environmental behaviour to anticipating potential damages on the ecosystem and coastal environment.

\section{ACKNOWLEDGEMENT}

The researchers would like to thank particular institutions and individuals who have contributed and supported this study, namely, the Institute of Research and Community Service of Universitas NegeriGorontalo, the Directorate General of Higher Education of the Ministry of Research, Technology and Higher Education (as Grant sponsor), the Department of Biology Faculty of Mathematics and Natural Science of Universitas Negeri Gorontalo, and the Center for Local Wisdom-based Coastal Ecology Studies (hence forth refers to PKEPKL).

\section{REFERENCES}

Aldila, E., 2013. Pengembangan LKS Terstruktur Berbasis Guided Discovery Learning (Penemuan Terbimbing) pada Pokok Bahasan Bangun Ruang Sisi Datar Kelas VIII Semester 2 SMP Negeri 2 Margorejo [The development of structured and guided discovery learning-based $L K S$ onthe topic of Geometry and Flat Side in Year VIII Semester 2 at the SMP Negeri 2Margorejo]. [Undergraduate Thesis]. IKIP PGRI Semarang.

Golar, Akhbar, H. Umar, I. Rachman, A.S. Alam, and E. Labiro, 2017. The Poverty Assessment basedon Subjective Criteria: Case Study of Rural Community near Protected Forest in Central Sulawesi. Australian Journal of Basic and Applied Sciences, 11(9): 22-30.

Mulyatiningsih, E., 2013. Metode Penelitian Terapan Bidang Pendidikan[Applied research methods in education]. Bandung: Alfabeta.

Nuangchalerm, P., 2010. Engaging Students to Perceive Nature of Science Through Socioscientific IssuesBased Instruction. European Journal of Social Sciences, 13(1): 34-37.

Nusantari, E., R. Utina, A.S. Katili, and Y. Tamu, 2017. Designing Learning Model in Learning Science Conservation Characterized with Local Wisdom Approach in Elementary School. The $1^{\text {st }}$ International Conference on Mathematics, Science, and Education. Universitas Negeri Malang.

Rachmawati, T and Daryanto, 2015. Teori Belajar dan Proses Pembelajaran yang Mendidik[Theories in learning and educative learning]. Yogyakarta: Gava Media.

Riyono, K., 2013. Pendekatan dan Strategi Pembelajaran [Approaches and strategies in learning). http://ebook_pengawasmadrasah.wordpress_pendekatansaintifik.pdf.

Subiantoro, A.W., 2011. Socioscientific Issues and Its Potency on Biology Instruction for Character Education in Indonesia; proceeding of The 4th International Conferenceon Science and Mathematics Education: "Transforming School Science and Mathematics Education in the 21st Century". SEAMEO RECSAM, Malaysia, 15-17..

Suparno, P., 2011. Teori Perkembangan Kognitif Jean Piaget (Cognitive development theory of Jean Piaget). Yogyakarta: Kanisius.

Suratsih, 2010. Pengembangan Modul Pembelajaran Biologi Berbasis Potensi Lokal dalam Kerangka Implementasi KTSP SMA di Yogyakarta [The development of local potential-based learning modules for Biology learning within the framework of the KTSP at high schools in Yogyakarta. [Undergraduate Thesis]. Universitas Negeri Yogyakarta. 
Utina, R., 2012. Kecerdasan Ekologis Dalam Kearifan Lokal Masyarakat Bajo Desa Torosiaje Provinsi Gorontalo [The ecological intelligence of thelocal wisdom of Bajo community in the village of Torosiaje in the Province of Gorontalo].

Utina, R and A.S., Katili, 2014. Pemanfaatan Ekosistem Mangrove Sebagai Media dan Sumber Belajar IPA Biologi Sekolah Dasar di Desa Kawasan Mangrove [The utilisation of mangrove ecosystem for learning media and resources for Biology subject at elementary school level in the village of mangrove area]. KKS_Pengabdian.Universitas Negeri Gorontalo.

Utina, R., 2016. Strategy of Conservation Coastal Biodiversity through Strengthening the Basic of Education (A strategy for elementary school level). The International Conference on Biodiversity 2016, joint of Universitas Negeri Gorontalo and The Society Biodiversity of Indonesia. Gorontalo.

Utina, R., 2017. Ecological Intelligence of Coastal Community onBiodiversity Conservation(case study of Bajau coastal communities in Gorontalo). Jurnal Metamorfosa IV(1):54-57(2017). Available onhttp://ojs.unud.ac.id/index.php/ metamorfosa.html. Diunduh tanggal.

Zeidler, D.L., 2005. Beyond STS: A Research-Based Framework for Socioscientific Issues Education. Journal of Science Education., 89(3): 357-377. 